\title{
Imaging biomarkers of diffuse liver disease: current status
}

\author{
Bachir Taouli $^{1,2}$ (1) Filipe Caseiro Alves ${ }^{3}$
}

Received: 26 April 2020 / Revised: 9 June 2020 / Accepted: 13 June 2020 / Published online: 25 June 2020

(c) Springer Science+Business Media, LLC, part of Springer Nature 2020

\begin{abstract}
We are happy to introduce this special issue of Abdominal Radiology on "diffuse liver disease". We have invited imaging experts to discuss various topics pertaining to diffuse liver disease, covering a vast array of imaging techniques including ultrasound (US), CT, MRI and new molecular imaging agents. Below, we briefly discussed the current status, limitations, and future directions of imaging biomarkers of diffuse liver disease.
\end{abstract}

Chronic liver disease (CLD) is highly prevalent worldwide, with high morbidity and mortality. Globally, it was estimated that 1.5 billion persons had CLD in 2017, most commonly resulting from NAFLD (nonalcoholic fatty liver disease), chronic hepatitis $\mathrm{B}(\mathrm{CHB})$ and $\mathrm{C}(\mathrm{CHC})$ viral infections and alcoholic liver disease [1]. CLD and liver cirrhosis are responsible for approximately 44,000 deaths in the USA and 2 million deaths worldwide each year, in addition to a high rate of morbidity and healthcare costs [2]. The epidemiology of CLD is changing, with the implementation of large-scale $\mathrm{CHB}$ vaccination and efficient $\mathrm{CHC}$ treatment with direct acting antivirals, the increasing prevalence of obesity and metabolic syndrome, and alcohol use disorder [2]. Indeed, approximately 2 billion adults are obese or overweight and over 400 million have diabetes worldwide; both of which are risk factors for NAFLD, nonalcoholic steatohepatitis (NASH) and hepatocellular carcinoma (HCC) [3].

Liver biopsy is the historical gold standard method to evaluate the degree of liver fibrosis, necroinflammation, fat and iron deposition, and to characterize unexplained etiologies of CLD (such as cholestatic disease) [4]. However, liver biopsy has major limitations, including invasiveness, risk of

Bachir Taouli

bachir.taouli@mountsinai.org

1 Department of Diagnostic, Molecular and Interventional Radiology, Icahn School of Medicine At Mount Sinai, 1470 Madison Avenue, New York, NY 10029, USA

2 BioMedical Engineering and Imaging Institute, Icahn School of Medicine At Mount Sinai, New York, NY, USA

3 Department of Radiology, University Hospital of Coimbra, Coimbra, Portugal sampling and observer variability, and is difficult to repeat (for example in the context of drug trials) [5-7].

Over the last 15 years, the successful implementation of noninvasive tests such as transient elastography (TE) [8-11], more recently ARFI (Acoustic Radiation Force Impulse) methods [12-15] and magnetic resonance elastography (MRE) [16-18], as well as simple and proprietary serum markers [19-21] have significantly reduced the need for liver biopsy for fibrosis staging. Liver stiffness measured with elastography techniques is now considered a reliable imaging biomarker of liver fibrosis in a wide range of etiologies. It is used to predict the degree of liver fibrosis (moderate vs advanced fibrosis and cirrhosis), predict the present of esophageal varices and portal hypertension, assess response to antiviral therapy in $\mathrm{CHC}[22,23]$, and provide prognostic information. TE is the most validated elastographic technique, with more recently implemented ARFI methods having overall equivalent performance to TE, while being integrated into clinical US systems allowing elastography to be performed in routine clinical examinations. MRE provides excellent diagnostic performance for fibrosis detection, superior than that of other techniques such as diffusionweighted imaging and dynamic contrast-enhanced MRI [24, 25]. However, MRE is less well validated in single etiology cohorts, and less available than US elastography methods.

There are several limitations of these noninvasive tests for detection of liver fibrosis as follows: liver stiffness is an indirect measure of fibrosis and is prone to confounders such as hepatic inflammation, congestion, cholestasis (for all elastographic methods), and steatosis (particularly for TE). Another limitation is the risk of inaccurate or failed measurement of liver stiffness, in patients with overweight/obesity and ascites with TE/ARFI. The 
development of the XL probe has improved the percentage of failed TE exams, while providing different liver stiffness values compared to the standard M probe [26]. MRE can also fail in patients with hepatic iron overload, ascites and obesity when using the GRE sequence [27, 28]. New EPI sequences are more immune to susceptibility artifacts from iron deposition [29].

As mentioned above, one of the urgent health issues in many countries around the world is the increasing number of patients with NAFLD and NASH. Liver fat quantification using MR spectroscopy and more recently proton density fat-fraction (PDFF) methods are now accepted as the reference, obviating the need for liver biopsy for diagnosis and quantification of steatosis [30,31]. However, markers of disease activity and severity based on elastography [32] and other methods are essential for establishing endpoints for ongoing active drug development efforts in NASH [33, 34]. Another component of liver disease is iron deposition quantified with $\mathrm{T} 2 *$ relaxometry, which is considered the reference for iron tissue concentration [35-38].

There are areas of active research that pertain to imaging of CLD that are also worth mentioning: MR relaxometry using native $\mathrm{T} 1$ or corrected $\mathrm{T} 1$ measurements used to measure the degree of hepatic inflammation which is an important component of disease activity, especially in NASH [39-42]; T1 relaxometry or relative enhancement post-gadoxetate injection which can inform not only about degree of liver fibrosis but also about the degree of severity of cirrhosis [43-47]; MR fingerprinting applied to liver disease providing a quick quantitative assessment [48]; new DCE-MRI acquisition and quantification methods [49-52]; improved 4D flow acquisition to quantify hemodynamic parameters that may be altered in CLD and portal hypertension [53-56]; texture analysis for fibrosis characterization [57-59]; deep learning models for detection of liver fibrosis [60-63]; and last but not least, MRI contrast agents with high collagen specificity for staging liver fibrosis (still in preclinical stage) [64, 65]. Finally, there has been recent interest in implementing abbreviated MRI protocols for diffuse liver disease (combining PDFF, T2* and MRE) [66] or for HCC screening [67-69]. These abbreviated protocols may improve MRI access and provide valuable information in a short amount of time.

In summary, the future of imaging in CLD is bright, and radiologists will continue with their mission of helping clinicians and patients make informed decisions regarding diagnosis, surveillance, therapy and prognosis. Some techniques still need clinical validation and/or need to be clinically translated. Considerations such as local expertise, cost and cost-effectiveness should be considered when choosing the appropriate test in CLD.

\section{References}

1. Global, regional, and national incidence, prevalence, and years lived with disability for 354 diseases and injuries for 195 countries and territories, 1990-2017: a systematic analysis for the Global Burden of Disease Study 2017 (2018). Lancet 392 (10159):1789-1858. https://doi.org/10.1016/S0140 $-6736(18) 32279-7$

2. Moon AM, Singal AG, Tapper EB (2019) Contemporary Epidemiology of Chronic Liver Disease and Cirrhosis. Clin Gastroenterol Hepatol. https://doi.org/10.1016/j.cgh.2019.07.060

3. Asrani SK, Devarbhavi H, Eaton J, Kamath PS (2019) Burden of liver diseases in the world. J Hepatol 70 (1):151-171. https ://doi.org/10.1016/j.jhep.2018.09.014

4. Goodman ZD (2007) Grading and staging systems for inflammation and fibrosis in chronic liver diseases. J Hepatol 47 (4):598607. https://doi.org/10.1016/j.jhep.2007.07.006

5. Bedossa P, Dargere D, Paradis V (2003) Sampling variability of liver fibrosis in chronic hepatitis C. Hepatology 38 (6):1449-1457

6. Poynard T, Imbert-Bismut F, Munteanu M, Ratziu V (2005) FibroTest-FibroSURE: towards a universal biomarker of liver fibrosis? Expert Rev Mol Diagn 5 (1):15-21

7. El-Badry AM, Breitenstein S, Jochum W, Washington K, Paradis V, Rubbia-Brandt L, Puhan MA, Slankamenac K, Graf R, Clavien PA (2009) Assessment of hepatic steatosis by expert pathologists: the end of a gold standard. Ann Surg 250 (5):691-697. doi:10.1097/SLA.0b013e3181bcd6ddhttps://doi. org/10.1097/SLA.0b013e3181bcd6dd

8. Castéra L, Vergniol J, Foucher J, Le Bail B, Chanteloup E, Haaser M, Darriet M, Couzigou P, de Lédinghen V (2005) Prospective comparison of transient elastography, Fibrotest, APRI, and liver biopsy for the assessment of fibrosis in chronic hepatitis C. Gastroenterology 128 (2):343-350. doi:10.1053/j. gastro.2004.11.018https://doi.org/10.1053/j.gastro.2004.11.018

9. Ziol M, Handra-Luca A, Kettaneh A, Christidis C, Mal F, Kazemi F, de Ledinghen V, Marcellin P, Dhumeaux D, Trinchet JC, Beaugrand M (2005) Noninvasive assessment of liver fibrosis by measurement of stiffness in patients with chronic hepatitis C. Hepatology 41 (1):48-54

10. Foucher J, Chanteloup E, Vergniol J, Castera L, Le Bail B, Adhoute X, Bertet J, Couzigou P, de Ledinghen V (2006) Diagnosis of cirrhosis by transient elastography (FibroScan): a prospective study. Gut 55 (3):403-408. https://doi.org/10.1136/ gut.2005.069153

11. Castera L, Forns X, Alberti A (2008) Non-invasive evaluation of liver fibrosis using transient elastography. J Hepatol 48 (5):835847. https://doi.org/10.1016/j.jhep.2008.02.008

12. Friedrich-Rust M, Wunder K, Kriener S, Sotoudeh F, Richter S, Bojunga J, Herrmann E, Poynard T, Dietrich CF, Vermehren J, Zeuzem S, Sarrazin C (2009) Liver fibrosis in viral hepatitis: noninvasive assessment with acoustic radiation force impulse imaging versus transient elastography. Radiology 252 (2):595604. doi: 10.1148/radiol.2523081928https://doi.org/10.1148/ radiol.2523081928

13. Sporea I, Sirli R, Bota S, Popescu A, Sendroiu M, Jurchis A (2012) Comparative Study Concerning the Value of Acoustic Radiation Force Impulse Elastography (ARFI) in Comparison with Transient Elastography (TE) for the Assessment of Liver Fibrosis in Patients with Chronic Hepatitis B and C. Ultrasound in Medicine \& Biology 38 (8):1310-1316. doi:10.1016/j. ultrasmedbio.2012.03.011https://doi.org/10.1016/j.ultrasmedb io.2012.03.011

14. Ferraioli G, Tinelli C, Dal Bello B, Zicchetti M, Filice G, Filice C, on behalf of the Liver Fibrosis Study G (2012) Accuracy of 
real-time shear wave elastography for assessing liver fibrosis in chronic hepatitis C: A pilot study. Hepatology 56 (6):21252133. https://doi.org/10.1002/hep.25936

15. Leung VY-f, Shen J, Wong VW-s, Abrigo J, Wong GL-h, Chim AM-l, Chu SH-t, Chan AW-h, Choi PC-l, Ahuja AT, Chan HL-y, Chu WC-w (2013) Quantitative Elastography of Liver Fibrosis and Spleen Stiffness in Chronic Hepatitis B Carriers: Comparison of Shear-Wave Elastography and Transient Elastography with Liver Biopsy Correlation. Radiology 269 (3):910-918. https://doi. org/10.1148/radiol.13130128

16. Yin M, Talwalkar JA, Glaser KJ, Manduca A, Grimm RC, Rossman PJ, Fidler JL, Ehman RL (2007) Assessment of hepatic fibrosis with magnetic resonance elastography. Clin Gastroenterol Hepatol 5 (10):1207-1213 e1202

17. Yin M, Glaser KJ, Talwalkar JA, Chen J, Manduca A, Ehman RL (2016) Hepatic MR Elastography: Clinical Performance in a Series of 1377 Consecutive Examinations. Radiology 278 (1):114124. https://doi.org/10.1148/radiol.2015142141

18. Kennedy P, Wagner M, Castera L, Hong CW, Johnson CL, Sirlin CB, Taouli B (2018) Quantitative Elastography Methods in Liver Disease: Current Evidence and Future Directions. Radiology 286 (3):738-763. https://doi.org/10.1148/radiol.2018170601

19. Salkic NN, Jovanovic P, Hauser G, Brcic M (2014) FibroTest/ Fibrosure for significant liver fibrosis and cirrhosis in chronic hepatitis B: a meta-analysis. Am J Gastroenterol 109 (6):796-809. https://doi.org/10.1038/ajg.2014.21

20. Lichtinghagen R, Pietsch D, Bantel H, Manns MP, Brand K, Bahr MJ (2013) The Enhanced Liver Fibrosis (ELF) score: normal values, influence factors and proposed cut-off values. J Hepatol 59 (2):236-242. https://doi.org/10.1016/j.jhep.2013.03.016

21. Xiao G, Zhu S, Xiao X, Yan L, Yang J, Wu G (2017) Comparison of laboratory tests, ultrasound, or magnetic resonance elastography to detect fibrosis in patients with nonalcoholic fatty liver disease: A meta-analysis. Hepatology 66 (5):1486-1501. https:// doi.org/10.1002/hep.29302

22. Tada T, Kumada T, Toyoda H, Sone Y, Takeshima K, Ogawa S, Goto T, Wakahata A, Nakashima M, Nakamuta M, Tanaka J (2018) Viral eradication reduces both liver stiffness and steatosis in patients with chronic hepatitis $\mathrm{C}$ virus infection who received direct-acting anti-viral therapy. Aliment Pharmacol Ther 47 (7):1012-1022. https://doi.org/10.1111/apt.14554

23. Elsharkawy A, Abdel Alem S, Fouad R, El Raziky M, El Akel W, Abdo M, Tantawi O, AbdAllah M, Bourliere M, Esmat G (2017) Changes in Liver stiffness measurements and Fibrosis scores following Sofosbuvir based treatment regimens without Interferon. Journal of Gastroenterology and Hepatology. https:// doi.org/10.1111/jgh. 13758

24. Dyvorne HA, Jajamovich GH, Bane O, Fiel MI, Chou H, Schiano TD, Dieterich D, Babb JS, Friedman SL, Taouli B (2016) Prospective comparison of magnetic resonance imaging to transient elastography and serum markers for liver fibrosis detection. Liver Int 36 (5):659-666. https://doi.org/10.1111/liv.13058

25. Wang Y, Ganger DR, Levitsky J, Sternick LA, McCarthy RJ, Chen ZE, Fasanati CW, Bolster B, Shah S, Zuehlsdorff S, Omary RA, Ehman RL, Miller FH (2011) Assessment of chronic hepatitis and fibrosis: comparison of MR elastography and diffusion-weighted imaging. AJR Am J Roentgenol 196 (3):553-561. https://doi. org/10.2214/AJR.10.4580

26. Myers RP, Pomier-Layrargues G, Kirsch R, Pollett A, Duarte-Rojo A, Wong D, Beaton M, Levstik M, Crotty P, Elkashab M (2012) Feasibility and diagnostic performance of the FibroScan XL probe for liver stiffness measurement in overweight and obese patients. Hepatology 55 (1):199-208. https://doi.org/10.1002/hep.24624

27. Wagner M, Corcuera-Solano I, Lo G, Esses S, Liao J, Besa C, Chen N, Abraham G, Fung M, Babb JS, Ehman RL, Taouli B (2017) Technical Failure of MR Elastography Examinations of the Liver: Experience from a Large Single-Center Study. Radiology:160863. https://doi.org/10.1148/radiol.2016160863

28. Ghoz HM, Kroner PT, Stancampiano FF, Bowman AW, Vishnu P, Heckman MG, Diehl NN, McLeod E, Nikpour N, Palmer WC (2019) Hepatic iron overload identified by magnetic resonance imaging-based $\mathrm{T} 2 *$ is a predictor of non-diagnostic elastography. Quantitative imaging in medicine and surgery 9 (6):921-927. https ://doi.org/10.21037/qims.2019.05.13

29. Wagner M, Besa C, Bou Ayache J, Yasar TK, Bane O, Fung M, Ehman RL, Taouli B (2016) Magnetic Resonance Elastography of the Liver: Qualitative and Quantitative Comparison of Gradient Echo and Spin Echo Echoplanar Imaging Sequences. Invest Radiol. https://doi.org/10.1097/RLI.0000000000000269

30. Yu H, Shimakawa A, McKenzie CA, Brodsky E, Brittain JH, Reeder SB (2008) Multiecho Water-Fat Separation and Simultaneous R*2 Estimation With Multifrequency Fat Spectrum Modeling. Magnetic Resonance in Medicine 60:1122-1134

31. Meisamy S, Hines CD, Hamilton G, Sirlin CB, McKenzie CA, Yu H, Brittain JH, Reeder SB (2011) Quantification of hepatic steatosis with T1-independent, T2-corrected MR imaging with spectral modeling of fat: blinded comparison with MR spectroscopy. Radiology 258 (3):767-775. https://doi.org/10.1148/radio 1.10100708

32. Imajo K, Kessoku T, Honda $\mathrm{Y}$, Tomeno W, Ogawa $\mathrm{Y}$, Mawatari H, Fujita K, Yoneda M, Taguri M, Hyogo H, Sumida Y, Ono M, Eguchi Y, Inoue T, Yamanaka T, Wada K, Saito S, Nakajima A (2016) Magnetic Resonance Imaging More Accurately Classifies Steatosis and Fibrosis in Patients With Nonalcoholic Fatty Liver Disease Than Transient Elastography. Gastroenterology 150 (3):626-637 e627. https://doi.org/10.1053/j.gastro.2015.11.048

33. Caussy C, Reeder SB, Sirlin CB, Loomba R (2018) Noninvasive, Quantitative Assessment of Liver Fat by MRI-PDFF as an Endpoint in NASH Trials. Hepatology 68 (2):763-772. https://doi. org/10.1002/hep.29797

34. Dulai PS, Sirlin CB, Loomba R (2016) MRI and MRE for noninvasive quantitative assessment of hepatic steatosis and fibrosis in NAFLD and NASH: Clinical trials to clinical practice. J Hepatol 65 (5):1006-1016. https://doi.org/10.1016/j.jhep.2016.06.005

35. St Pierre TG, Clark PR, Chua-anusorn W, Fleming AJ, Jeffrey GP, Olynyk JK, Pootrakul P, Robins E, Lindeman R (2005) Noninvasive measurement and imaging of liver iron concentrations using proton magnetic resonance. Blood 105 (2):855-861

36. Gandon Y, Olivie D, Guyader D, Aube C, Oberti F, Sebille V, Deugnier Y (2004) Non-invasive assessment of hepatic iron stores by MRI. Lancet 363 (9406):357-362

37. Wood JC, Enriquez C, Ghugre N, Tyzka JM, Carson S, Nelson MD, Coates TD (2005) MRI R2 and R2* mapping accurately estimates hepatic iron concentration in transfusion-dependent thalassemia and sickle cell disease patients. Blood 106 (4):1460-1465

38. d'Assignies G, Paisant A, Bardou-Jacquet E, Boulic A, Bannier E, Laine F, Ropert M, Morcet J, Saint-Jalmes H, Gandon Y (2018) Non-invasive measurement of liver iron concentration using 3-Tesla magnetic resonance imaging: validation against biopsy. Eur Radiol 28 (5):2022-2030. https://doi.org/10.1007/s0033 0-017-5106-3

39. Hoad CL, Palaniyappan N, Kaye P, Chernova Y, James MW, Costigan C, Austin A, Marciani L, Gowland PA, Guha IN, Francis ST, Aithal GP (2015) A study of T(1) relaxation time as a measure of liver fibrosis and the influence of confounding histological factors. NMR Biomed 28 (6):706-714. https://doi.org/10.1002/ nbm.3299

40. Heye T, Yang SR, Bock M, Brost S, Weigand K, Longerich T, Kauczor HU, Hosch W (2012) MR relaxometry of the liver: significant elevation of T1 relaxation time in patients with liver cirrhosis. Eur Radiol 22 (6):1224-1232. https://doi.org/10.1007/ s00330-012-2378-5 
41. Cassinotto C, Feldis M, Vergniol J, Mouries A, Cochet H, Lapuyade B, Hocquelet A, Juanola E, Foucher J, Laurent F, De Ledinghen V (2015) MR relaxometry in chronic liver diseases: Comparison of T1 mapping, T2 mapping, and diffusionweighted imaging for assessing cirrhosis diagnosis and severity. Eur J Radiol 84 (8):1459-1465. https://doi.org/10.1016/j.ejrad 2015.05.019

42. Pavlides M, Banerjee R, Sellwood J, Kelly CJ, Robson MD, Booth JC, Collier J, Neubauer S, Barnes E (2016) Multiparametric magnetic resonance imaging predicts clinical outcomes in patients with chronic liver disease. J Hepatol 64 (2):308-315. https://doi. org/10.1016/j.jhep.2015.10.009

43. Haimerl M, Utpatel K, Verloh N, Zeman F, Fellner C, Nickel D, Teufel A, Fichtner-Feigl S, Evert M, Stroszczynski C, Wiggermann P (2017) Gd-EOB-DTPA-enhanced MR relaxometry for the detection and staging of liver fibrosis. Scientific reports 7:41429. https://doi.org/10.1038/srep41429

44. Bastati N, Beer L, Mandorfer M, Poetter-Lang S, Tamandl D, Bican Y, Elmer MC, Einspieler H, Semmler G, Simbrunner B, Weber M, Hodge JC, Vernuccio F, Sirlin C, Reiberger T, BaSsalamah A (2020) Does the Functional Liver Imaging Score Derived from Gadoxetic Acid-enhanced MRI Predict Outcomes in Chronic Liver Disease? Radiology 294 (1):98-107. https://doi. org/10.1148/radiol.2019190734

45. Bastati N, Feier D, Wibmer A, Traussnigg S, Balassy C, Tamandl D, Einspieler H, Wrba F, Trauner M, Herold C, Ba-Ssalamah A (2014) Noninvasive differentiation of simple steatosis and steatohepatitis by using gadoxetic acid-enhanced MR imaging in patients with nonalcoholic fatty liver disease: a proof-of-concept study. Radiology 271 (3):739-747. https://doi.org/10.1148/radio 1.14131890

46. Feier D, Balassy C, Bastati N, Fragner R, Wrba F, Ba-Ssalamah A (2016) The diagnostic efficacy of quantitative liver MR imaging with diffusion-weighted, SWI, and hepato-specific contrastenhanced sequences in staging liver fibrosis--a multiparametric approach. Eur Radiol 26 (2):539-546. https://doi.org/10.1007/ s00330-015-3830-0

47. Ba-Ssalamah A, Bastati N, Wibmer A, Fragner R, Hodge JC, Trauner M, Herold CJ, Bashir MR, Van Beers BE (2017) Hepatic gadoxetic acid uptake as a measure of diffuse liver disease: Where are we? J Magn Reson Imaging 45 (3):646-659. https:// doi.org/10.1002/jmri.25518

48. Chen Y, Jiang Y, Pahwa S, Ma D, Lu L, Twieg MD, Wright KL, Seiberlich N, Griswold MA, Gulani V (2016) MR Fingerprinting for Rapid Quantitative Abdominal Imaging. Radiology 279 (1):278-286. https://doi.org/10.1148/radiol.2016152037

49. Feng L, Axel L, Chandarana H, Block KT, Sodickson DK, Otazo R (2016) XD-GRASP: Golden-angle radial MRI with reconstruction of extra motion-state dimensions using compressed sensing. Magn Reson Med 75 (2):775-788. https://doi.org/10.1002/ mrm. 25665

50. Mansour R, Thibodeau Antonacci A, Bilodeau L, Vazquez Romaguera L, Cerny M, Huet C, Gilbert G, Tang A, Kadoury S (2020) Impact of temporal resolution and motion correction for dynamic contrast-enhanced MRI of the liver using an accelerated golden-angle radial sequence. Phys Med Biol 65 (8):085004. https ://doi.org/10.1088/1361-6560/ab78be

51. Weiss J, Ruff C, Grosse U, Grozinger G, Horger M, Nikolaou K, Gatidis S (2019) Assessment of Hepatic Perfusion Using GRASP MRI: Bringing Liver MRI on a New Level. Invest Radiol 54 (12):737-743. https://doi.org/10.1097/RLI.0000000000000586

52. Pahwa S, Liu H, Chen Y, Dastmalchian S, O'Connor G, Lu Z, Badve C, Yu A, Wright K, Chalian H, Rao S, Fu C, Vallines I, Griswold M, Seiberlich N, Zeng M, Gulani V (2018) Quantitative perfusion imaging of neoplastic liver lesions: A multi-institution study. Scientific reports 8 (1):4990. https://doi.org/10.1038/s4159 8-018-20726-1

53. Bane O, Peti S, Wagner M, Hectors S, Dyvorne H, Markl M, Taouli B (2019) Hemodynamic measurements with an abdominal 4D flow MRI sequence with spiral sampling and compressed sensing in patients with chronic liver disease. J Magn Reson Imaging 49 (4):994-1005. https://doi.org/10.1002/jmri.26305

54. Dyvorne H, Knight-Greenfield A, Jajamovich G, Besa C, Cui Y, Stalder A, Markl M, Taouli B (2015) Abdominal 4D flow MR imaging in a breath hold: combination of spiral sampling and dynamic compressed sensing for highly accelerated acquisition. Radiology 275 (1):245-254. https://doi.org/10.1148/radiol.14140 973

55. Motosugi U, Roldan-Alzate A, Bannas P, Said A, Kelly S, Zea R, Wieben O, Reeder SB (2019) Four-dimensional Flow MRI as a Marker for Risk Stratification of Gastroesophageal Varices in Patients with Liver Cirrhosis. Radiology 290 (1):101-107. https ://doi.org/10.1148/radiol.2018180230

56. Roldan-Alzate A, Frydrychowicz A, Niespodzany E, Landgraf BR, Johnson KM, Wieben O, Reeder SB (2013) In vivo validation of 4D flow MRI for assessing the hemodynamics of portal hypertension. J Magn Reson Imaging 37 (5):1100-1108.https:// doi.org/10.1002/jmri.23906

57. Lubner MG, Malecki K, Kloke J, Ganeshan B, Pickhardt PJ (2017) Texture analysis of the liver at MDCT for assessing hepatic fibrosis. Abdom Radiol (NY) 42 (8):2069-2078. https:// doi.org/10.1007/s00261-017-1096-5

58. Naganawa S, Enooku K, Tateishi R, Akai H, Yasaka K, Shibahara J, Ushiku T, Abe O, Ohtomo K, Kiryu S (2018) Imaging prediction of nonalcoholic steatohepatitis using computed tomography texture analysis. Eur Radiol 28 (7):3050-3058. https://doi. org/10.1007/s00330-017-5270-5

59. Cannella R, Borhani AA, Tublin M, Behari J, Furlan A (2019) Diagnostic value of MR-based texture analysis for the assessment of hepatic fibrosis in patients with nonalcoholic fatty liver disease (NAFLD). Abdom Radiol (NY) 44 (5):1816-1824. https:// doi.org/10.1007/s00261-019-01931-6

60. Schawkat K, Ciritsis A, von Ulmenstein S, Honcharova-Biletska H, Jungst C, Weber A, Gubler C, Mertens J, Reiner CS (2020) Diagnostic accuracy of texture analysis and machine learning for quantification of liver fibrosis in MRI: correlation with MR elastography and histopathology. Eur Radiol. https://doi.org/10.1007/ s00330-020-06831-8

61. Choi KJ, Jang JK, Lee SS, Sung YS, Shim WH, Kim HS, Yun J, Choi JY, Lee Y, Kang BK, Kim JH, Kim SY, Yu ES (2018) Development and Validation of a Deep Learning System for Staging Liver Fibrosis by Using Contrast Agent-enhanced CT Images in the Liver. Radiology 289 (3):688-697. https://doi.org/10.1148/ radiol.2018180763

62. Liu Y, Ning Z, Ormeci N, An W, Yu Q, Han K, Huang Y, Liu D, Liu F, Li Z, Ding H, Luo H, Zuo C, Liu C, Wang J, Zhang C, Ji J, Wang W, Wang Z, Wang W, Yuan M, Li L, Zhao Z, Wang G, Li M, Liu Q, Lei J, Liu C, Tang T, Akcalar S, Celebioglu E, Ustuner E, Bilgic S, Ellik Z, Asiller OO, Liu Z, Teng G, Chen Y, Hou J, Li X, He X, Dong J, Tian J, Liang P, Ju S, Zhang Y, Qi X (2020) Deep Convolutional Neural Network-aided Detection of Portal Hypertension in Patients With Cirrhosis. Clin Gastroenterol Hepatol. https://doi.org/10.1016/j.cgh.2020.03.034

63. Wang K, Lu X, Zhou H, Gao Y, Zheng J, Tong M, Wu C, Liu C, Huang L, Jiang T, Meng F, Lu Y, Ai H, Xie XY, Yin LP, Liang P, Tian J, Zheng R (2019) Deep learning Radiomics of shear wave elastography significantly improved diagnostic performance for assessing liver fibrosis in chronic hepatitis B: a prospective multicentre study. Gut 68 (4):729-741. https://doi.org/10.1136/gutjn 1-2018-316204 
64. Farrar CT, Gale EM, Kennan R, Ramsay I, Masia R, Arora G, Looby K, Wei L, Kalpathy-Cramer J, Bunzel MM, Zhang C, Zhu Y, Akiyama TE, Klimas M, Pinto S, Diyabalanage H, Tanabe KK, Humblet V, Fuchs BC, Caravan P (2018) CM-101: Type I Collagen-targeted MR Imaging Probe for Detection of Liver Fibrosis. Radiology 287 (2):581-589. https://doi.org/10.1148/radiol.20171 70595

65. Salarian M, Turaga RC, Xue S, Nezafati M, Hekmatyar K, Qiao J, Zhang Y, Tan S, Ibhagui OY, Hai Y, Li J, Mukkavilli R, Sharma M, Mittal P, Min X, Keilholz S, Yu L, Qin G, Farris AB, Liu ZR, Yang JJ (2019) Early detection and staging of chronic liver diseases with a protein MRI contrast agent. Nature communications 10 (1):4777. https://doi.org/10.1038/s41467-019-11984-2

66. Cunha GM, Villela-Nogueira CA, Bergman A, Lobo Lopes FPP (2018) Abbreviated mpMRI protocol for diffuse liver disease: a practical approach for evaluation and follow-up of NAFLD. Abdom Radiol (NY) 43 (9):2340-2350. https://doi.org/10.1007/ s00261-018-1504-5

67. Besa C, Lewis S, Pandharipande PV, Chhatwal J, Kamath A, Cooper N, Knight-Greenfield A, Babb JS, Boffetta P, Padron N, Sirlin CB, Taouli B (2017) Hepatocellular carcinoma detection: diagnostic performance of a simulated abbreviated MRI protocol combining diffusion-weighted and T1-weighted imaging at the delayed phase post gadoxetic acid. Abdom Radiol (NY) 42 (1):179-190. https://doi.org/10.1007/s00261-016-0841-5

68. Marks RM, Ryan A, Heba ER, Tang A, Wolfson TJ, Gamst AC, Sirlin CB, Bashir MR (2015) Diagnostic per-patient accuracy of an abbreviated hepatobiliary phase gadoxetic acid-enhanced MRI for hepatocellular carcinoma surveillance. AJR Am J Roentgenol 204 (3):527-535. https://doi.org/10.2214/AJR.14.12986

69. Vietti Violi N, Lewis S, Liao J, Hulkower M, Hernandez-Meza G, Smith K, Babb JS, Chin X, Song J, Said D, Kihira S, Sirlin CB, Reeder SB,Bashir MR, Fowler KJ, Ferket BS, Sigel K, Taouli B. Gadoxetate-enhanced abbreviated MRI is highly accurate for hepatocellular carcinomascreening. Eur Radiol (in press)

Publisher's Note Springer Nature remains neutral with regard to jurisdictional claims in published maps and institutional affiliations. 